\title{
Mechanical and Barrier Properties of Composite Films Based on Kappa-Carrageenan-Polyvinyl Alcohol
}

\author{
HE Irianto, Agusman, D Fransiska, Musfira
}

\begin{abstract}
Optimization of film formula-based kappa-carrageenan and polyvinyl alcohol (PVA) was studied using a two-level, two-factor Design Expert $11{ }^{\circledR}$ by Response Surface Methodology (RSM) Central Composite Design (CCD). The aim of this study was to obtain the optimal concentration of kappa-carrageenan and polyvinyl alcohol in producing films. The influence composition $k$-carrageenan and polyvinyl alcohol was characterized. The results showed the effects of $k$-carrageenan and polyvinyl alcohol had a significant effect on the response thickness, tensile strength, burst strength, elongation, solubility, water vapor barrier, opacity, color, and moisture content. The optimized condition for production $k$-carrageenan and PVA was $1.21 \%$ carrageenan and $1.93 \%$ polyvinyl alcohol, which was giving film with thickness 0.044 $\mathrm{mm}$, tensile strength $16.69 \mathrm{MPa}$, burst strength $167.86 \mathrm{kPa}$, elongation $81.79 \%$, water solubility $65.04 \%$, water vapor permeability $7.49 \mathrm{~g} / \mathrm{m}$ s Pa $\times 10-11$, opacity 2.31, $\Delta E$ 2.42, and moisture content $19.13 \%$.
\end{abstract}

Index Terms: Central Composite Design, Composite film k-Carrageenan, Polyvinyl alcohol.

\section{INTRODUCTION}

The use of plastics in various countries is quite large. Plastics play an significant role in keeping up the quality, safety, transport, storage and display of food products (Kerry $\&$ Huber, 2009). A type of plastic produced from refined petroleum synthetic polymer is not biodegradable by microorganisms, which can create an environmental problem (Sina, 2013). Furthermore, synthetic polymers used in the manufacture of plastics can also migrate into food is reaction of substances in packaging material with food component that harm to health (Piringer \& Baner, 2008). emergence of new food products that require packaging in the process of distribution and marketing. The type of packaging used is growing and has led to new packaging that has a good ability to maintain the quality of food, environmentally friendly, easy to decompose (biodegradable) and non-toxic to the environment (Boredes, Pollet, \& Avérous, 2009). Biodegradable biopolymer packaging materials from renewable sources is an option to replace plastic from oil-based polymer (Vieira, Da Silva, Dos Santos, \& Beppu,

Revised Manuscript Received on September 22, 2019.

HE Irianto,

Agusman,

D Fransiska,

Musfira
The rapid development of the food industry leads to the

2011). Renewable natural resources of plant or animal origin are raw material for biopolymers. Films are made from three different constituent materials are hydrocolloids, lipids, and composites (McHugh \& Krochta, 1994). Carrageenan has been regarded one of the foremost promising natural renewable resources, has admitted attention because of its lower cost, biodegradability, thermoplastic behavior (Meng et al., 2018). Carrageenan is a hydrocolloid extracted from Eucheuma and Kappaphycus. Among the various types of seaweed, Eucheuma and Kappaphycus are the main producers of kappa and iota carrageenan. In general, $\kappa$-carrageenan has the capability to form a strong and rigid gel that meliorates its film-forming capability (Balqis, Nor Khaizura, Russly, \& Nur Hanani, 2017). Futhermore, carrageenan is safely applied as packaging or food coating material(Choi et al., 2005).

Polyvinyl alcohol (PVA), a biodegradable polymer, has characteristic to produce film with a good characteristic (Maria, de Carvalho, Sobral, Habitante, \& Solorza-Feria, 2008), biocompatible (Limpan, Prodpran, Benjakul, \& Prasarpran, 2012). PVA as a film-forming solution to improve mechanical properties (Muppalla, Kanatt, Chawla, \& Sharma, 2014). PVA films show relatively good results due to low water vapor permeability and increased tensile strength (Shahbazi, Rajabzadeh, Rafe, \& Ettelaie, 2017). However, the rate of use of PVA has limited or specific level for each type of food product that cannot be over used. PVA is an appropriate material for food-packaging applications, due to the characteristics features of its mechanical properties (Tripathi, Mehrotra, \& Dutta, 2010). Overall, the study of renewable natural materials of carrageenan and PVA for bioplastic is carried out to be developed into food packaging and is a promising replacement for synthetic polymer.

\section{Material AND MethodS}

\section{A. Material}

K-carrageenan (obtained from E.cottoni extraction) and PVA (Merck), corn starch (Maizenaku) were used as received to the film forming solution. Glycerol was used as the plasticizer.

\section{B. Film preparation}

The films were produced using to the protocol describe by Thakur et al. (2017). The k-carrageenan and corn starch were

\section{Published By:}

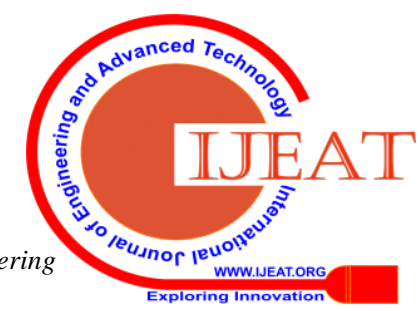


dissolved in $100 \mathrm{ml}$ distilled water, and homogenized by stirring with hot plate magnetic stirrer for 15 minutes. The solutions were heated at $80^{\circ} \mathrm{C}$ and steady stirred to form a clear transparent solution. After blending the solution, PVA was dissolved in hot distilled water and was mixed to the clear transparent solution. As the plasticizer, glycerol $1 \%$ was added to the solution. Final film forming solutions were obtained after blending all the film forming mixtures by stirring on a magnetic stirrer for 15 minutes. $30 \mathrm{ml}$ of final films solution were casted into casting plates, and dried at room temperature for 24 hour followed by drying in the oven for 24 hour.

\section{Film characterization}

In order to obtain an accurate measurement of the thickness, tensile strength, burst strength, elongation, water solubility, water vapor permeability, opacity, color and moisture content of films, all of the films were kept in desiccators contained saturated solution of sodium bromide (58\% relative humidity, 25oC) for 48 hour prior testing.

\section{1) Thickness}

A digital micrometer (Mitutoyo Serial No. 7301, Mitutoyo Corp., Japan) with a $0.001 \mathrm{~mm}$ accuracy was used to measure films thickness. Thickness is the average of measurements taken at ten distinct random locations of each film. Thickness is report in $\mathrm{mm}$.

\section{2) Mechanical properties}

Mechanical properties of film were including tensile strength, elongation and burst strength. Tensile strength and elongation of films were measured with texture analyzer (TAXT Plus (Balqis et al., 2017). Films were cut into $2 \mathrm{~cm} \mathrm{x}$ $15 \mathrm{~cm}$ and fixed in the film grips. The initial distance of grip separation, and test speed was set at $10 \mathrm{~cm}$ and $3 \mathrm{~mm} / \mathrm{sec}$, respectively. Tensile strength was calculated by dividing maximum force with initial cross-sectional area of film. Elongation is percentage of change in the length of film strips from the initial length.

Burst strength was measured according to ASTM (1995). Films were cut into $10 \mathrm{~cm} \times 10 \mathrm{~cm}$, and fixed in the film support ring. The films were given maximum force to rupture the films at a constant velocity $3 \mathrm{~mm} / \mathrm{s}$. Burst strength value is maximum force divided by film cross section. Tensile strength, elongation, burst strength were calculated automatically using the software Texture Expert V.1.15. Tensile strength, elongation value were average of seven replicates of each films, since burst strenght value was average of three replicates.

\section{3) Solubility}

Film solubility was analyzed following protocol explained by Maran, Sivakumar, Sridhar, and Thirugnanasambandham (2013). Films were cut ( $2 \mathrm{~cm} \times 2 \mathrm{~cm})$, weighed (M0), and moved into beaker glass containing $50 \mathrm{ml}$ distillated water. The beaker glasses were sealed and incubated at $25^{\circ} \mathrm{C}$ for 24 $\mathrm{h}$ with periodically shaken. The films were dried at $40^{\circ} \mathrm{C}$ in the oven until a constant weight (M1) of films were obtained. The total soluble matter of the films were calculated as follows.

$$
\text { solubility (\%) }=\frac{M_{0}-M_{1}}{M_{1}} \times 100 \%
$$

\section{4) Water vapor permeability}

WVP test was measured gravimetrically, according to procedures described by Maran et al. (2013). Each films samples was fixed on a permeation cell containing $10 \mathrm{~g}$ $\mathrm{CaCl} 2$ granule $(0 \% \mathrm{RH}, 25 \mathrm{oC})$. Permeation cell was transfered in a desiccator containing saturated $\mathrm{NaCl}$ solution $\left(75 \% \mathrm{RH}, 25^{\circ} \mathrm{C}\right)$. After 3 hour (steady state condition reached), the weight gain of the permeation cell was counted as water vapor transport. Weight gaint of permeation cell was regularly evaluated (about $1 \mathrm{~h}$ ) and the changes in the weight was plotted as a function of time. From the plots, the slope $(\mathrm{g} / \mathrm{s})$ was calculated through linear regression, and then the water vapor transmission rate (WVTR) value was slope $(\mathrm{g} / \mathrm{s})$ divided by the transfer area (m2). After the test, the thickness of film was measured and WVP ( $\mathrm{g} \mathrm{m}-1 \mathrm{~s}-1 \mathrm{~Pa}-1)$ was computed as follows:

$$
\text { WVP }(\%)=\frac{\text { WVTR }}{S\left(R_{1}-R_{2}\right) d}
$$

Where $\mathrm{S}$ is the saturation vapor pressure of water $(\mathrm{Pa})$ at $25^{\circ}$. R1, R2 and $\mathrm{d}$ is $\mathrm{RH}$ in the desiccator, $\mathrm{RH}$ in the permeation cell and $\mathrm{d}$ film thickness $(\mathrm{m})$, respectively.

\section{5) Color and opacity}

A colorimeter (ColorFlex EX, HunterLab) was used to measure color and opacity of film. The color, represented as the difference in color $\left(\Delta \mathrm{E}^{*}\right)$, was determined following method described in literature (Denavi et al., 2009). An white tile $\left(\mathrm{L}^{*}=94.20, \mathrm{a}^{*}=1.09, \mathrm{~b}^{*}=2.55\right)$ was used as the film background and it colour parameter were used to calculating the differentials between the color parameter $(\Delta \mathrm{L}, \Delta \mathrm{a}$ and $\Delta \mathrm{b})$ of samples and the films background. That differentials between the color parameter was used to caulculated $\Delta \mathrm{E}$, as follow

$$
\Delta \mathrm{E}=\sqrt{\Delta \mathrm{L}^{*_{2}}+\Delta \mathrm{a}^{* 2}+\Delta \mathrm{b}^{{ }^{2 / 2}}}
$$

Film opacity was measured using ColorFlex EX, following machine's standard protocol. The measurement is a two-part program metric where the CIE Y (luminance or brightness) value is first measured the sample backed by a black tile, followed by a second measurement of the $\mathrm{Y}$ value of the sample backed by a white tile. The resulting fraction is expressed as Y\%, calculated as follows:

$$
\text { Opacity }(\mathrm{Y} \%)=\frac{\mathrm{Y} \text { black }}{\mathrm{Y} \text { white }} \times 100 \%
$$

6) Moisture content

Film were cut and weighed $2 \mathrm{~g}$ as initial weight (M0) was recorded. Then film is drying at $105^{\circ} \mathrm{C}$ for $24 \mathrm{~h}$, the final dry weights (M1) of the film sample was determined and the moisture content (MC) was calculated as follow (Zhong \& Li, 2011) :

$$
\mathrm{MC}(\%)=\frac{M_{0}-M_{1}}{M_{1}} \times 100 \%
$$

\section{Experiment design and statistical analysis}

RSM design called Central Composite Design (CCD) was choosed in this study the relationship concentration of kappa carrageenan (X1) and PVA (X2) in response to thickness, mechanical properties (TS, EL, and BT), solubility (SOL), water vapor permeability 
(WVP), color $(\Delta \mathrm{E})$, opacity $(\mathrm{Y} \%)$ and moisture contain (MC) of the films. The levels of independent variables were defined according to a 22 factorial. Each independent variable was coded at two level between +1 and -1 as shown in Table 1. A total of 13 experimental runs which was consist of eight factorial point and five replications at the center are presented in Table 2.

Data were analyzed using software Design Expert 11.. The initial estimation of the data is done by looking at the fit summary section to determine the model of the suggested equation (suggested) by the program. Furthermore, analysis of variance (ANOVA) was performed with the selected model. Model significant if the p-value less than 0.05. In addition the to the model, the p-value of "Prob> F" was also analyzed in the lack of fit. Coefficient of determination R2 is used to check the quality of the fit of the polynomial model equation, and then the value of adjusted-R2 of model were used to confimed the model adequacies. The appropriate model will be displayed in a three-dimensional graph. The next step of optimization is determined by criteria that include variables and each response that affects. Design-Expert 11 will display some optimal solutions with different desirability values. An optimal solutions that have desirability values close to 1 tend to be chosen as the best solution and to be verified.

TABLE 1: THE TWO-FACTOR TWO LEVEL DESIGN (24) FOR CHARACTERIZATION OF FILM

\begin{tabular}{lllll}
\hline Independent variable & Coded & Level & \\
& & -1 & 0 & 1 \\
\hline Kappa-carrageenan & $X_{1}$ & 0.5 & 1 & 5 \\
Poly (vinyl alcohol) & $X_{2}$ & 1 & 2 & 3 \\
\hline
\end{tabular}

\section{RESULT AND DISCUSSION}

RSM is a statistical method used to study the relationship between variable(s) to optimize the response (Montgomery, 2001). In the present study Central Composite Design (CCD), an RSM methods, is used to develop the model sand evaluate the effects of $\mathrm{k}$ - carrageenan $\left(X_{1}\right)$ and polyvinyl alcohol $\left(X_{2}\right)$ on film characteristic. The result were shown in Table. 2

\begin{tabular}{|c|c|c|c|c|c|c|c|c|c|c|c|c|c|c|}
\hline \multirow[t]{3}{*}{ Run } & \multicolumn{2}{|c|}{ Variable } & \multicolumn{12}{|c|}{ Response } \\
\hline & $\mathrm{KC}$ & PVA & THI & TSI & BS & EL & SOL & WVTR & OP & $\Delta \mathrm{L}^{*}$ & $\Delta \mathrm{a}^{*}$ & $\Delta \mathrm{b}^{*}$ & $\Delta \mathrm{E}$ & MS \\
\hline & $\left(\mathrm{X}_{1}\right)$ & $\left(\mathrm{X}_{2}\right)$ & $\mathrm{Mm}$ & $\mathrm{MPa}$ & $\mathrm{MPa}$ & $\%$ & $\%$ & $\mathrm{~g} / \mathrm{Pa}-\mathrm{s}-1$ & $\%$ & & & & & \\
\hline 1 & 0.50 & 1.00 & 0.028 & 10.75 & 56.29 & 65.30 & 78.40 & 8.03 & 0.9 & -1.50 & -0.06 & 0.31 & 1.53 & 20.23 \\
\hline 2 & 1.50 & 1.00 & 0.036 & 11.85 & 162.39 & 22.26 & 69.70 & 8.38 & 2.3 & -2.35 & -0.05 & 0.63 & 2.44 & 19.22 \\
\hline 3 & 0.50 & 3.00 & 0.041 & 17.32 & 166.91 & 113.40 & 32.72 & 5.47 & 1.2 & -1.68 & -0.04 & 0.59 & 1.78 & 16.62 \\
\hline 4 & 1.50 & 3.00 & 0.048 & 18.06 & 220.65 & 54.56 & 33.30 & 5.69 & 2.4 & -2.58 & -0.08 & 0.80 & 2.67 & 15.47 \\
\hline 5 & 0.29 & 2.00 & 0.046 & 12.42 & 99.93 & 119.86 & 63.62 & 6.15 & 0.6 & -1.14 & -0.07 & 0.39 & 1.21 & 19.99 \\
\hline 6 & 1.71 & 2.00 & 0.034 & 14.82 & 196.43 & 37.93 & 57.80 & 7.01 & 2.8 & -2.69 & -0.04 & 0.65 & 2.76 & 17.19 \\
\hline 7 & 1.00 & 0.59 & 0.047 & 9.67 & 64.53 & 42.63 & 82.35 & 8.81 & 1.5 & -2.01 & -0.05 & 0.65 & 2.11 & 20.63 \\
\hline 8 & 1.00 & 3.41 & 0.030 & 19.23 & 257.33 & 92.46 & 23.84 & 4.51 & 2.2 & -2.10 & -0.06 & 0.67 & 2.21 & 15.74 \\
\hline 9 & 1.00 & 2.00 & 0.043 & 17.24 & 165.68 & 97.70 & 60.30 & 7.35 & 2.0 & -2.19 & -0.08 & 0.71 & 2.30 & 19.36 \\
\hline 10 & 1.00 & 2.00 & 0.044 & 17.14 & 169.46 & 90.33 & 62.80 & 7.38 & 2.0 & -2.16 & -0.07 & 0.68 & 2.27 & 19.73 \\
\hline 11 & 1.00 & 2.00 & 0.044 & 16.48 & 160.24 & 98.90 & 69.90 & 7.58 & 2.0 & -2.16 & -0.08 & 0.63 & 2.25 & 19.67 \\
\hline 12 & 1.00 & 2.00 & 0.043 & 16.58 & 163.28 & 96.90 & 65.73 & 7.20 & 2.1 & -2.23 & -0.04 & 0.38 & 2.26 & 19.42 \\
\hline 13 & 1.00 & 2.00 & 0.045 & 17.23 & 163.77 & 98.16 & 66.25 & 7.25 & 2.1 & -2.07 & -0.06 & 0.56 & 2.14 & 19.01 \\
\hline
\end{tabular}

KC: kappa-carrageenan, PVA : ploy vinyl alcohol, THI : thickness, TS :tensile strength, EL : elongation, BS : burst strength, SO ; solubility, WVTR : water vapor permeability, OP : transparency, MS : moisture contain.

\section{A. The fit summary}

Each response data from the study were analyzed to obtain

\begin{tabular}{|c|c|c|c|c|c|c|c|c|c|c|c|c|}
\hline Source & $\begin{array}{l}\text { Sum of } \\
\text { Square }\end{array}$ & DF & Mean Square & F-Value & Prob $>F$ & $\mathrm{R}^{2}$ & Adj- $R^{2}$ & PredR $^{2}$ & Press & C.V. & $\begin{array}{l}\text { Adeq } \\
\text { Precisio } \\
\mathrm{n}\end{array}$ & Remaks \\
\hline \multicolumn{13}{|l|}{ Thickness } \\
\hline Mean & 0.021 & 1 & 0.021 & & & & & & & & & \\
\hline Linear & 0.0004 & 2 & 0.0004 & 29,41 & 0.0002 & 0.88 & 0.82 & 0.72 & 0,0001 & & & \\
\hline $2 \mathrm{FI}$ & $2.500 \mathrm{E}-08$ & 1 & $2.500 \mathrm{E}-08$ & 0,310 & 0.8741 & 0.88 & 0.80 & 0.58 & 0.0002 & & & \\
\hline Quadratic & 0.0001 & 2 & 0.0000 & 71.57 & $\begin{array}{l}<0.000 \\
1\end{array}$ & 0.99 & 0.98 & 0.97 & 0.0001 & 1.88 & 38.384 & Suggested \\
\hline Cubic & $1.535 \mathrm{E}-04$ & 2 & $3.001 \mathrm{E}-07$ & 0.4894 & 0.9085 & 0.99 & 0.98 & 0.84 & 0.0001 & & & Aliased \\
\hline Residual & $3.925 \mathrm{E}-08$ & 5 & $7.850 \mathrm{E}-08$ & & & & & & & & & \\
\hline
\end{tabular}
are four types of polynomial models that mean, linear, quadratic, and cubic, from the four types of models, one model will be selected that best matches the results of the response measurement. The result were shown in Table.3.

TABLE 3. SUMMARY OF SQUARE MODEL AND SUMMARY OF MODEL STATISTICAL RESPONSES

the polynomial models as measured by the response. There 
Mechanical and Barrier Properties of Composite Films Based on Kappa-Carrageenan-Polyvinyl Alcohol

\begin{tabular}{|c|c|c|c|c|c|c|c|c|c|c|c|c|}
\hline Source & $\begin{array}{l}\text { Sum of } \\
\text { Square }\end{array}$ & DF & Mean Square & F-Value & Prob $>F$ & $\mathrm{R}^{2}$ & $\operatorname{Adj}-R^{2}$ & PredR $^{2}$ & Press & C.V. & $\begin{array}{l}\text { Adeq } \\
\text { Precisio } \\
\mathrm{n}\end{array}$ & Remaks \\
\hline Total & 0.022 & 13 & 0.0018 & & & & & & & & & \\
\hline \multicolumn{13}{|l|}{$\begin{array}{l}\text { Tensile } \\
\text { Strength }\end{array}$} \\
\hline Mean & 3039.80 & 1 & 3039.80 & & & & & & & & & \\
\hline Linear & 89.88 & 2 & 44.94 & 18.83 & 0.0004 & 0.78 & 0.74 & 0.66 & 38.43 & & & \\
\hline $2 \mathrm{FI}$ & 0.0324 & 1 & 0.0324 & 0.0122 & 0.9124 & 0.78 & 0.71 & 0.58 & 48.83 & & & \\
\hline Quadratic & 22.41 & 2 & 11.30 & 42.14 & $\begin{array}{l}<0.000 \\
1\end{array}$ & 0.98 & 0.97 & 0.94 & 8.41 & 3.39 & 26.983 & Suggested \\
\hline Cubic & 0.3808 & 2 & 0.1898 & 0.9484 & 0.4482 & 0.99 & 0.97 & 0.6 & 28.98 & & & Aliased \\
\hline Residual & 0.9883 & 5 & 0.1983 & & & & & & & & & \\
\hline Total & 3143.08 & 13 & 242.49 & & & & & & & & & \\
\hline \multicolumn{13}{|l|}{$\begin{array}{l}\text { Burst } \\
\text { Strength }\end{array}$} \\
\hline Mean & 9.679E-03 & 1 & $9.679 \mathrm{E}-04$ & & & & & & & & & \\
\hline Linear & 45554.03 & 2 & 22777.02 & 19.2 & 0.0004 & 0.79 & 0.75 & 0.63 & $\begin{array}{l}20798.4 \\
2\end{array}$ & & & \\
\hline $2 \mathrm{FI}$ & 460.96 & 1 & 460.96 & 0.36 & 0.5613 & 0.8 & 0.73 & 0.54 & $\begin{array}{l}26180.2 \\
5\end{array}$ & & & \\
\hline Quadratic & 11283.1 & 2 & 5641.55 & 326.02 & $\begin{array}{l}<0.000 \\
1\end{array}$ & 0.99 & 0.99 & 0.98 & 735.78 & 2.35 & 20.876 & Suggested \\
\hline Cubic & 83.4 & 2 & 41.7 & 5.53 & 0.0541 & 0.99 & 0.99 & 0.98 & 1001.6 & & & Aliased \\
\hline Residual & 37.73 & 5 & 7.55 & & & & & & & & & \\
\hline Total & $1025 \mathrm{E}-04$ & 13 & 78873.22 & & & & & & & & & \\
\hline \multicolumn{13}{|l|}{ Elongation } \\
\hline Mean & 81669.5 & 1 & 81669.5 & & & & & & & & & \\
\hline Linear & 8771.92 & 2 & 4385.96 & 15.46 & 0.0009 & 0.75 & 0.7 & 0.59 & 4694.09 & & & \\
\hline $2 \mathrm{FI}$ & 62.41 & 1 & 62.41 & 0.2 & 0.6634 & 0.76 & 0.68 & 0.32 & 7816.33 & & & \\
\hline Quadratic & 2515.01 & 2 & 1257.51 & 33.94 & 0.0002 & 0.97 & 0.96 & 0.86 & 1577.42 & 7.68 & 22.284 & Suggested \\
\hline Cubic & 36.78 & 2 & 18.39 & 0.41 & 0.6823 & 0.98 & 0.95 & 0.03 & $\begin{array}{l}11241.4 \\
2\end{array}$ & & & Aliased \\
\hline Residual & 222.6 & 5 & 44.52 & & & & & & & & & \\
\hline Total & 93278.23 & 13 & 7175.25 & & & & & & & & & \\
\hline \multicolumn{13}{|l|}{$\begin{array}{l}\text { Water } \\
\text { Solubility }\end{array}$} \\
\hline Mean & 45218.79 & 1 & 45218.79 & & & & & & & & & \\
\hline Linear & 3429.35 & 2 & 1714.68 & 38.13 & $\begin{array}{l}<0.000 \\
1\end{array}$ & 0.88 & 0.86 & 0.8 & 750.49 & & & \\
\hline $2 \mathrm{FI}$ & 21.53 & 1 & 21.53 & 0.45 & 0.518 & 0.88 & 0.85 & 0.71 & 1104.23 & & & \\
\hline Quadratic & 352.26 & 2 & 176.14 & 16.26 & 0.0023 & 0.98 & 0.96 & 0.93 & 245.03 & 5.58 & 26.060 & Suggested \\
\hline Cubic & 0.057 & 2 & 0.028 & $1.878 \mathrm{E}-02$ & 0.9981 & 0.98 & 0.95 & 0.6 & 1538.71 & & & Aliased \\
\hline Residual & 75.78 & 5 & 15.16 & & & & & & & & & \\
\hline Total & 49097.79 & 13 & 3776.75 & & & & & & & & & \\
\hline
\end{tabular}




\begin{tabular}{|c|c|c|c|c|c|c|c|c|c|c|c|c|}
\hline Source & $\begin{array}{l}\text { Sum of } \\
\text { Square }\end{array}$ & DF & Mean Square & F-Value & Prob $>F$ & $\mathrm{R}^{2}$ & Adj- $R^{2}$ & PredR $^{2}$ & Press & C.V. & $\begin{array}{l}\text { Adeq } \\
\text { Precisio } \\
\mathrm{n} \\
\end{array}$ & Remaks \\
\hline \multicolumn{13}{|c|}{$\begin{array}{l}\text { Water } \\
\text { Vapor } \\
\text { Permeability }\end{array}$} \\
\hline Mean & 634.34 & 1 & 634.34 & & & & & & & & & \\
\hline Linear & 16.45 & 2 & 8.22 & 55.72 & $\begin{array}{l}<0.000 \\
1\end{array}$ & 0.91 & 0.9 & 0.86 & 2.47 & & & \\
\hline $2 \mathrm{FI}$ & $4.225 \mathrm{E}-02$ & 1 & $4.225 \mathrm{E}-03$ & 0.026 & 0.8759 & 0.91 & 0.89 & 0.84 & 2.82 & & & \\
\hline Quadratic & 1.1 & 2 & 0.55 & 10.3 & 0.0082 & 0.97 & 0.96 & 0.87 & 2.18 & 3.31 & 25.534 & Suggested \\
\hline Cubic & 0.14 & 2 & 0.069 & 1.48 & 0.3137 & 0.96 & 0.96 & 0.46 & 9.64 & & & Aliased \\
\hline Residual & 0.23 & 5 & 0.047 & & & & & & & & & \\
\hline Total & 652.27 & 13 & 50.17 & & & & & & & & & \\
\hline \multicolumn{13}{|l|}{ Opacity } \\
\hline Mean & 43.94 & 1 & 43.94 & & & & & & & & & \\
\hline Linear & 4.23 & 2 & 2.12 & 52.85 & $\begin{array}{l}<0.000 \\
1 \\
\end{array}$ & 0.91 & 0.89 & 0.85 & 0.66 & & & \\
\hline $2 \mathrm{FI}$ & $1.000 \mathrm{E}-03$ & 1 & $1.000 \mathrm{E}-03$ & 0.23 & 0.6425 & 0.91 & 0.88 & 0.78 & 0.97 & & & \\
\hline Quadratic & 0.33 & 2 & 0.17 & 20.17 & 0.0012 & 0.98 & 0.97 & 0.92 & 0.34 & 4.94 & 32.733 & Suggested \\
\hline Cubic & 0.044 & 2 & 0.022 & 8.39 & 0.0253 & 0.99 & 0.99 & 0.97 & 0.099 & & & Aliased \\
\hline Residual & 0.013 & 5 & $2.650 \mathrm{E}-04$ & & & & & & & & & \\
\hline Total & 48.57 & 13 & 3.74 & & & & & & & & & \\
\hline \multicolumn{13}{|l|}{ Color } \\
\hline Mean & 60.01 & 1 & 60.01 & & & & & & & & & \\
\hline Linear & 2.04 & 2 & 1.02 & 65.62 & $\begin{array}{l}<0.000 \\
1\end{array}$ & 0.91 & 0.92 & 0.87 & 0.28 & & & \\
\hline $2 \mathrm{FI}$ & $1.000 \mathrm{E}-02$ & 1 & $1.000 \mathrm{E}-03$ & $5.793 \mathrm{E}-03$ & 0.941 & 0.9 & 0.92 & 0.83 & 0.36 & & & \\
\hline Quadratic & 0.1 & 2 & 0.052 & 7.25 & 0.0197 & 0.96 & 0.97 & 0.87 & 0.28 & 3.96 & 24.442 & Suggested \\
\hline Cubic & 0.034 & 2 & 0.017 & 4.92 & 0.0658 & 0.96 & 0.99 & 0.92 & 0.16 & & & Aliased \\
\hline Residual & 0.017 & 5 & $3.407 \mathrm{E}-03$ & & & & & & & & & \\
\hline Total & 62.2 & 13 & 4.78 & & & & & & & & & \\
\hline \multicolumn{13}{|l|}{$\begin{array}{l}\text { Moisture } \\
\text { Content }\end{array}$} \\
\hline Mean & 4515.35 & 1 & 4515.35 & & & & & & & & & \\
\hline Linear & 30.16 & 2 & 15.08 & 22.69 & 0.0002 & 0.81 & 0.78 & 0.70 & 11.01 & & & \\
\hline $2 \mathrm{FI}$ & $4.900 \mathrm{E}-04$ & 1 & $4.9000 \mathrm{E}-0,4$ & $6.640 \mathrm{E}-0,4$ & 0.9368 & 0.81 & 0.75 & 0.47 & 19.37 & & & \\
\hline Quadratic & 5.38 & 2 & 2.69 & 14.9 & 0.003 & 0.96 & 0.94 & 0.80 & 7.16 & 2.28 & 18.158 & Suggested \\
\hline Cubic & 0.43 & 2 & 0.21 & 1.29 & 0.358 & 0.97 & 0.94 & 0.10 & 32.83 & & & Aliased \\
\hline Residual & 0.83 & 5 & 0.17 & & & & & & & & & \\
\hline Total & 4552.16 & 13 & 350.17 & & & & & & & & & \\
\hline
\end{tabular}

Quadratic (quadratic model) was a suitable model for the response as indicated in summary of square model. The regression equations were obtained by fitting of the data to types polynomial model (linear, interactive, quadratic and cubic model) (Maran et al. 2013). The polynomial equation obtained on the basis of Central Composite Design (CCD) using four models to understand the correlation of interaction between variables with the response following : 


$$
\begin{aligned}
& \text { THI }=0.044+0.026 \mathrm{X}_{1}+0,016 \mathrm{X}_{2}-0.012 \mathrm{X}_{1} X_{2}-0.03 \mathrm{X}_{1}^{2}-0039 \mathrm{X}_{2}^{2} \\
& \text { TSI }=12.35+4.32 \mathrm{X}_{1}+8.63 \mathrm{X}_{2}-0.712 X_{1} X_{2}-13.01 \mathrm{X}_{1}^{2}-10.29 \mathrm{X}_{2}^{2} \\
& \mathrm{BS}=163.35+7.46 \mathrm{X}_{1}+33.53 \mathrm{X}_{2}-0.912 X_{1} X_{2}-16.01 \mathrm{X}_{1}^{2}-11.19 \mathrm{X}_{2}^{2} \\
& \mathrm{EL}=96.40-27.22 \mathrm{X}_{1}+18.86 \mathrm{X}_{2}-3.95 X_{1} X_{2}-11.09 \mathrm{X}_{1}^{2}-16.76 \mathrm{X}_{2}^{2} \\
& \text { SOL }=65.00+2,04 \mathrm{X}_{1}-20.60 \mathrm{X}_{2}+2.32 \mathrm{X}_{1} X_{2}-2.99 \mathrm{X}_{1}^{2}-6.79 \mathrm{X}_{2}^{2}
\end{aligned}
$$$$
\mathrm{WVP}=7.35+0.223 \mathrm{X}_{1}-1.42 \mathrm{X}_{2}-0.0325 \mathrm{X}_{1} \mathrm{X}_{2}-0.3179 \mathrm{X}_{1}^{2}-0.2779 \mathrm{X}_{2}^{2}
$$$$
\mathrm{OP}=2.04+0.7139 \mathrm{X}_{1}-0.1737 \mathrm{X}_{2}-0.050 \mathrm{X}_{1} \mathrm{X}_{2}-0.1887 \mathrm{X}_{1}^{2}-0.1138 \mathrm{X}_{2}^{2}
$$$$
\Delta \mathrm{E}=2.24+0.4990 \mathrm{X}_{1}-0.077 \mathrm{X}_{2}-0.0050 \mathrm{X}_{1} \mathrm{X}_{2}-0.1214 \mathrm{X}_{1}^{2}-0.0339 \mathrm{X}_{2}^{2}
$$$$
\text { MS }=19.44+0.765 \mathrm{X}_{1}+1.78 \mathrm{X}_{2}-0.0350 \mathrm{X}_{1} \mathrm{X}_{2}-0.5496 \mathrm{X}_{1}^{2}-0.7521 \mathrm{X}_{2}^{2}
$$

Coefficient of determination $\mathrm{R}^{2}$, adjusted coefficient $\left(\mathrm{R}^{2} \mathrm{Adj}\right)$ and predicted coefficient $\left(\mathrm{R}^{2}\right.$ Pred) were used to evaluated the quality of the fit of the polynomial model. The adequacy and fitness of the model were indicted by coefficient of determination $\left(\mathrm{R}^{2}\right)$ (Halim, Kamaruddin, \& Fernando, 2009), the $\mathrm{R}^{2}$ coefficients values were range between 0 and 1 (Noordin, Venkatesh, Sharif, Elting, \& Abdullah, 2004). In the present study, the $\mathrm{R}^{2}$ values indicated a high degree of correlation of models, where the $\mathrm{R}^{2}$ values were $0.99,0.98,0.99,0.97,0.98,0.97,0.98,0.96,0.96$ for THI, TS, BT, EL, SOL, WVP, OP, $\triangle \mathrm{E}, \mathrm{MS}$, respectively. The $\mathrm{R}^{2}$ which approach 1 ensures to fit of the square model to the responses (Ghosh \& Swaminathan, 2003). The value of adj- $\mathrm{R}^{2}$ was $0.98,0.97,0.99,0.96,0.96,0.96,0.97,0.97,0.94$ for THI, TS, BT, EL, SOL, WVP, OP, $\triangle E$, MS. The adj-R ${ }^{2}$ value is useful when comparing models with different number of terms. The predicted- $\mathrm{R}^{2}$ (pred $\mathrm{R}^{2}$ ) is a measure of how good

\begin{tabular}{|c|c|c|c|c|c|c|c|c|c|c|}
\hline Source & Thickness & Tensile & Burst & Elongation & Solubility & WVP & Opacity & $\Delta \mathrm{E}$ & Moisture & \\
\hline Model & $<0.0001$ & $<0.0001$ & $<0.0001$ & $<0.0001$ & $<0.0001$ & $<0.0001$ & $<0.0001$ & $<0.0001$ & $<0.0001$ & Significant \\
\hline $\mathrm{X}_{1}$-Karaginan & $<0.0001$ & 0.0065 & $<0.0001$ & $<0.0001$ & 0.01225 & 0.0291 & $<0.0001$ & $<0.0001$ & 0.0014 & \\
\hline $\mathrm{X}_{2}$-PVA & $<0.0001$ & $<0.0001$ & $<0.0001$ & $<0.0001$ & $<0.0001$ & $<0.0001$ & 0.0035 & 0.0362 & $<0.0001$ & \\
\hline $\mathrm{X}_{1} \mathrm{X}_{2}$ & 0.5334 & 0.5454 & $<0.0001$ & 0.2355 & 0.2015 & 0.7865 & 0.3072 & 0.9097 & 0.8738 & \\
\hline$X_{I}^{2}$ & $<0.0001$ & $<0.0001$ & $<0.0001$ & 0.002 & 0.048 & 0.0084 & 0.0014 & 0.007 & 0.0113 & \\
\hline$X_{2}^{2}$ & $<0.0001$ & 0.0009 & $<0.0001$ & 0.0002 & 0.001 & 0.0156 & 0.0032 & 0.3281 & 0.0023 & \\
\hline Lack of fit & 0.6438 & 0.0672 & 0.7689 & 0.0604 & 0.6622 & 0.0921 & 0.0752 & 0.1461 & 0.1153 & Not Significant \\
\hline
\end{tabular}
the model is estimating the of response, and comparison of predR ${ }^{2}$ with the adj- $\mathrm{R}^{2}$ should be around 0.20 of adjusted $\mathrm{R}^{2}$ (Rouhi, Razavi, \& Mousavi, 2017). The value of predR ${ }^{2}$

TABLE 4. RESULT ANALYSIS VARIANCE (ANOVA) FOR RESPONSE SURFACE QUADRATIC MODEL.

Lack of fit of the model is statically insignificant ( $p$-value bigger than 0.05$)$. The value lack of fit were calculated 0.64 , $0.06,0.06,0.66,0.09,0.07,0.14,0.11$ for thickness, tensile strength, burst, elongation, water vapor permeability, opacity, color, moisture content. The insignificant Lack of fit value is a good model requirement because it indicates the suitability of the response value (Noordin et al., 2004).

\section{A. Effect of variable}

\section{1) Thickness}

Film thickness is a significant parameter to determine the physical characteristics of films (Kanatt, Rao, Chawla, \& Sharma, 2012). The increased concentration of carrageenan and PVA led to an increase in total solids thus increasing the
(0.97, 0.94, 0.98, 0.86, 0.93, 0.87, 0.92, 0.87, 0.86) for THI, TS, BT, EL, SOL, WVP, OP, $\triangle \mathrm{E}, \mathrm{MS}$.

Coefficient of variance $(\mathrm{CV})$ is the ratio of the standard error of estimate to the mean value of the observed (Liyana-Pathirana \& Shahidi, 2005). The CV model were calculated 1.88, 3.36, 2.35, 7.68, 5.58, 3.31, 4.94, 3.96, 2.28 for THI, TS, BT, EL, SOL, WVP, OP, $\triangle \mathrm{E}$, MS Coefficient of variation with a very low value (not greater than 10\%) indicates good suitability of research data(Ghafari, Aziz, Isa, \& Zinatizadeh, 2009).

The accuracy of a model is predicted from adeq precision. The adequate precision assess the 'signal to noise ratio (Sharma, Khanna, Gupta, \& Sharma, 2013). The adequate precision model were calculated $38.384,26.983,20.876$, 22.284, 26.060, 25.534, 32.733, 24.442, 18.158 for THI, TS, BT, EL, SOL, WVP, OP, $\triangle \mathrm{E}, \mathrm{MS}$. Adeq precision with a value greater than 4 is a good model accuracy (Muthukumar, Mohan, \& Rajendran, 2003).

The predicted sum of squares (PRESS) was calculated $0.0001,8.41,735.78,1577.42,245.03,2.18,0.34,0.28,7.16$ for THI, TS, BT, EL, SOL, WVP, OP, $\triangle \mathrm{E}$, MS. PRES) is an indicator how a particular model fits point in the design (Beg, Sahai, \& Gupta, 2003) and small PRESS values is desired (Ramakrishnan \& Arumugam, 2012).

Analysis variance (ANOVA)

In this case, the ANOVA confirms the adequacy of the quadratic. Analysis of Variance (ANOVA) was applied to find the interaction between the variables carrageenan (X1) PVA (X2) and the responses (thickness, tensile, burst, elongation, water vapor permeability, opacity, color, moisture content). Table 4 show that models is significantly (less than 0.05), an significant model is necessary in terms that model have significant influence on response.

thickness of film. Table 2 showed that carrageenan/PVA is significantly affected on the thickness of film. The thickness of film carrageenan/PVA was lower than gum/PVA (Monjazeb Marvdashti, Koocheki, \& Yavarmanesh, 2017), carrageenan/gum and clay (Martins et al., 2013). The thickness of film depend on the nature and composition of the films forming mixture (Galus \& Lenart, 2013).

2) Mechanical properties

Tensile strength (TS) is defined as the highest tensile stress that can be maintained by the film until break (Balqis et al., 2017). The higher the tensile strength of the resultant film will be better. In this study it 
was found that the increasing concentration of carrageenan and PVA directly proportional to the tensile strength of the resulting. Meng et al. (2018) reported that carrageenan has ion $\mathrm{K}$ which can strengthen the tensile results of the film. In otherhands polyvinyl alcohol gives a greater influence in increasing the tensile strength of film because PVA has a higher degree of hydrolysis and molecular weight. Limpan et al. (2012) found that films made with higher degree hydrolysis PVA showed higher tensile strength. A higher degree of hydrolysis increases the number of hydroxyl groups present in PVA molecules. The EOH group of PVA and hydroxyl group of carrageenan form hydrogen bond that will interact so as to increase tensile strength. Higher tensile strength of carrageenan and polyvinyl alcohol film was correlated with the existence of hydrogen bonds between PVA molecules and carrageenan, those bonds made the film matrix far denser and stronger (Shahbazi et al., 2017). The result was similar with Tang and Alavi (2011), the PVA is as polar substances that has hydroxyl groups $(-\mathrm{OH})$ in their chemical structure, those polar hydroxyl groups tend to form hydrogen bonds between molecules and intramolecular which increase tensile strength. Muppalla et al. (2014) reported increase in PVA concentration resulted to increase in tensile strength of film. The result were similar to Bonilla, Fortunati, Atarés, Chiralt, and Kenny (2014) film Chitosan PVA that tensile strength increase with increasing PVA.

Inversely, the elongation percentage decreases with increasing concentration of carrageenan but PVA increases. Film with agar, carrageenan, conjack, A/C/K have lower elongation film than carrageenan film (Rhim \& Wang, 2013). Carrageenan/PVA films have higher elongation than chitosan/PVA films (Srinivasa, Ramesh, Kumar, \& Tharanathan, 2003), FMP/PVA'(Limpan, Prodpran, Benjakul, \& Prasarpran, 2010), polysaccharide rice starch (Detduangchan, Sridach, \& Wittaya, 2014), rice starch/chitosan (Bourtoom \& Chinnan, 2008). The burst tester is designed for measuring the bursting strength of packaging material (ASTM, 2018). The results show Table 2 concentrations of carrageenan and PVA.

\section{3) Water solubility}

Degress solubility of film in water is the decisive factor biodegradability, when used as packaging. There are films that require high levels of solubility or vice versa, depending on the type of product to be packaged. Carrageenan/PVA dissolved in water (Tavassoli-Kafrani, Shekarchizadeh, \& Masoudpour-Behabadi, 2016). Reported carrageenan is a water-soluble polymer which their solubility depends on the content esters sulfate and the presence of cations contained. Arvind Soni and Kumar (2016) finding film from carbohydrate molecule easily dissolved in water, thus more soluble. PVA has low solubility because it has a high degree of hydrolysis. This is according to a statement Limpan et al. (2012) found a low degree of hydrolysis completely soluble in water while the low solubility obtained with a degree of hydrolysis and high molecular weight. Silva (2008) found that the water solubility of the gelatin-PVA film decreased from $35.3 \%$ to $15.5 \%$ with increasing the degree of hydrolysis of PVA. that bursting strength increases with increasing

\section{4) Water vapor permeability}

WVP is the most important for deciding the appropriate food products for each packaging material (Woranuch, Yoksana, \& Akashi, 2015). The results show that the rate of water vapor permeability increases with increasing concentration of carrageenan and inversely proportional to the concentration of PVA. Carrageenan is a polysaccharide that has hydrophilic properties in the film matrix, the more the use of carrageenan, the greater the value of WVP due to the tendency of carrageenan which has a hydroxyl $(\mathrm{OH})$ group so that it absorbs more water. Film research from carrageenan has been carried out by Rhim and Wang (2013), that the higher the carrageenan concentration the rate of water vapor permeability is increasing. Larotonda, Torres, Gonçalves, Sereno, and Hilliou (2016) also reported the hydrophilic character showed relatively high-water vapor permeability

PVA lowers the value of the water vapor permeability because polyvinyl alcohols have fewer hydroxyl groups so that the absorption of water is also less. the result were similar of Limpan et al. (2012) that polyvinyl alcohol (PVA) is able to absorb and release water vapor because it has an $\mathrm{OH}$ group in its molecular structure. $\mathrm{H} 2 \mathrm{O}$ molecules are polar. Ions $\mathrm{O}$ negatively charged water vapor binds to $\mathrm{H}$ ions on $\mathrm{OH}$ groups. Film carrageenan/PVA was lower than carrageenan/oil essential (Shojaee-Aliabadi et al., 2014), carrageenan/sorbitol (Farhan \& Hani, 2017).

\section{5) Opacity and color}

Packaging film has an influence on the appearance and consumer acceptance of the product (Kurt \& Kahyaoglu, 2014), carrageenan and PVA have an effect on the opacity value, the opacity will increase with increasing carrageenan concentration. Increasing the concentration of polysaccharides will increase film opacity (Garcia, Pinotti, \& Zaritzky, 2006). Film PVA to be transparent so that with the addition of polyvinyl alcohol will decrease the value of the opacity of the film (Monjazeb Marvdashti et al., 2017). Pure PVA films show higher transparency (low opacity), the results agree to Balqis et al. (2017), the PVA and water molecules interact that might change the index of refractive thereby reducing opacityof film. Similar trend was also perceived for chitosan and PVA films where chitosan tend to produce film with highest opacity while PVA tend to produce film with lowest opacity (Kanatt et al., 2012).

Color is indicated by the value of $\mathrm{L} *, \mathrm{a} *, \mathrm{~b} *$. In general, the carrageenan and PVA films have $\mathrm{L} *$ higher, $\mathrm{a} *$ lower and $\mathrm{b} *$ lower. The PVA used affects the overall color. Combining PVA can reduce the yellowish of carrageenan-based films. According to Thakur et al. (2017), addition of PVA obviously increases the brightness $\left(\mathrm{L}^{*}\right)$ value and decreases the value of $b^{*}$. Futhermore, Monjazeb Marvdashti et al (2017) found that that $L^{*}$ of chitosan-PVA films were increased with the addition of PVA. Differences in values $\mathrm{L}^{*}$, $\mathrm{a} *$ and $\mathrm{b} *$ were obtaine by compared to standard. 

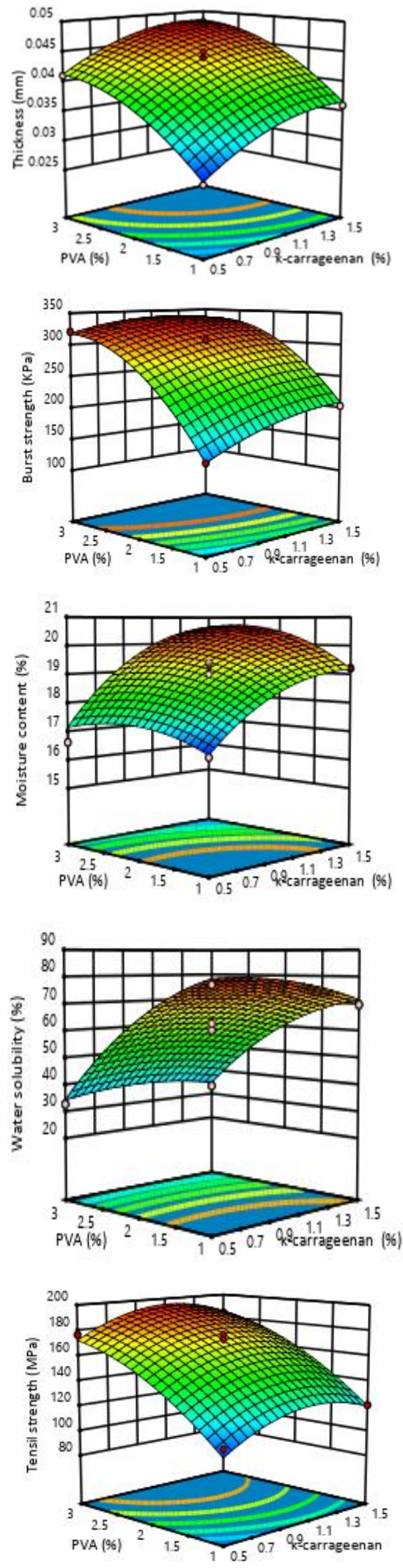
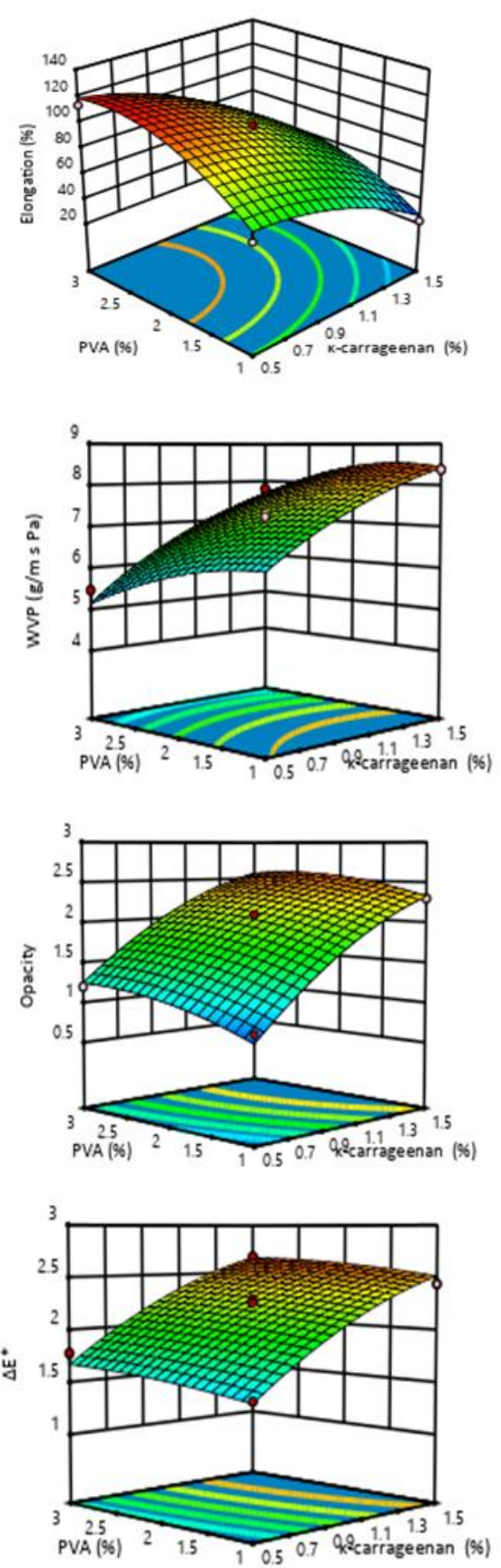

Fig.1 Respond surface plot the interaction effect of PVA and carrageenan on thickness, tensile strength, burst strength, elongation, water solubility, water vapor permeability, opacity, color $(\Delta \mathrm{E})$, color expressed by the value of $\Delta \mathrm{E}$. The greater the value of $\Delta \mathrm{E}$ the greater the color difference with the standard.

\section{6) Moisture content}

The packaging film must maintain moisture in protecting the packaged product. Therefore, the film moisture content is the most important parameter in food packaging application. Film moisture content decreases with increasing concentration of carrageenan and PVA. Carvalho et al. (2009) studied film gelatin/PVA reported PVA directly related to the hydrolysis degree or molecular weight and character hydrophilic. The moisture content film carrageenan/ PVA was lower than starch/ascorbic acid (Zhong \& Li, 2011).

Optimization of film

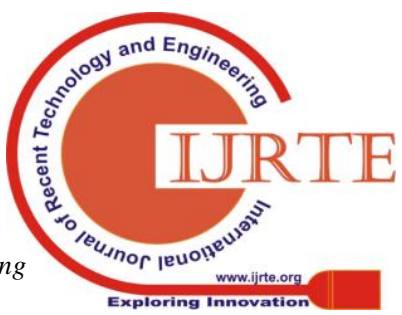


Based on the optimization using the Design Expert DX 11 program, the RSM design recommends the optimum formula for Producing film The calculation result obtained by the optimized conditions kappa-carrageenan $1.21 \%$ and polyvinyl alcohol $1.93 \%$ with the result of thickness 0.043 $\mathrm{mm}$, tensile strength $16.71 \mathrm{MPa}$, burst strength $166.95 \mathrm{kPa}$, elongation $81.86 \%$, water solubility $64.92 \%$, water vapor permeability $7.23 \mathrm{~g} / \mathrm{m} \mathrm{s} \mathrm{Pa} \mathrm{x} 10^{-11}$, opacity $2.3, \Delta \mathrm{E} 2.41$, and moisture content $19.06 \%$. The desirability value of the optimization performed is 0.939 , which means that the chance of the process conditions to produce film with the characteristics that correspond with the optimization target is $93.9 \%$. The value of desirability is to determine the degree of accuracy of the results of the optimal solution (Singh, Chatli, \& Sahoo, 2015).

\section{B. Verification}

The optimal conditions obtained are carried out for verification to compare the results predicted of the response. The calculation result showed kappa-carrageenan $1.21 \%$ and polyvinyl alcohol $1.93 \%$ with the result of thickness 0.044 $\mathrm{mm}$, tensile strength $16.69 \mathrm{MPa}$, burst strength $167.86 \mathrm{kPa}$, elongation $81.79 \%$, water solubility $65.04 \%$, water vapor permeability $7.49 \mathrm{~g} / \mathrm{m} \mathrm{s} \mathrm{Pa} \quad x 10^{-11}$, opacity $2.31, \Delta \mathrm{E} 2.42$, and moisture content $19.13 \%$. The results obtained through confirmation indicate compliance with the predictive value and this optimal value is valid according to the specified parameters

\section{CONCluSion}

Kappa-carrageenan and PVA had a significant effect $(\mathrm{P}<0.05)$ on the response thickness, tensile strength, burst strength, elongation, water solubility, WVP, opacity, color and moisture content. The optimum formulation film based carrageenan/PVA was found to be carrageenan of $1.21 \%$, PVA $1.93 \%$, respectively.

\section{REFERENCES}

[1] Arvind Soni, G. K., S.K. Mendiratta, Vivek Shukla and, \& Kumar, A. (2016). Development and characterization of essential oils incorporated carrageenan based edible film for packaging of chicken patties. Nutrition \& Food Science, Vol. 46 No, pp. 82-95.

[2] ASTM. (1995). Standard Test Method for Bursting Strength of Textile Fabrics- Diaphragm Burst Method. ASTM International.

[3] Standard Test Method for Bursting Strength of Textile Fabrics-Diaphragm Bursting Strength Tester Method (2018).

[4] Balqis, A., Nor Khaizura, M. A. R., Russly, A. R., \& Nur Hanani, Z. A. (2017). Effects of plasticizers on the physicochemical properties of kappa-carrageenan films extracted from Eucheuma cottonii. International Journal of Biological Macromolecules, 103, 721-732. doi: 10.1016/j.ijbiomac.2017.05.105

[5] Beg, Q. K., Sahai, V., \& Gupta, R. (2003). Statistical media optimization and alkaline protease production from Bacillus mojavensis in a bioreactor. Process Biochemistry, 39, 203-209. doi: 10.1016/S0032-9592(03)00064-5

[6] Bonilla, J., Fortunati, E., Atarés, L., Chiralt, A., \& Kenny, J. M. (2014). Physical, structural and antimicrobial properties of poly vinyl alcohol-chitosan biodegradable films. Food
Hydrocolloids, $\quad 35$,

10.1016/j.foodhyd.2013.07.002

[7] Boredes, P., Pollet, E., \& Avérous, L. (2009). Nano-biocomposites: Biodegradable polyester/nanoclay systems. Progress in Polymer Science, 34, 125-155.

[8] Bourtoom, T., \& Chinnan, M. S. (2008). Preparation and properties of rice starch e chitosan blend biodegradable film. 41, 1633-1641. doi: 10.1016/j.lwt.2007.10.014

[9] Carvalho, R. A., Maria, T. M. C., Moraes, I. C. F., Bergo, P. V. A., Kamimura, E. S., Habitante, A. M. Q. B., \& Sobral, P. J. A. (2009). Study of some physical properties of biodegradable films based on blends of gelatin and poly(vinyl alcohol) using a response-surface methodology. Materials Science and Engineering: $\quad C, \quad 29(2), \quad 485-491 . \quad$ doi https://doi.org/10.1016/j.msec.2008.08.030

[10] Choi, J. H., Choi, W. Y., Cha, D. S., Chinnan, M. J., Park, H. J., Lee, D. S., \& Park, J. M. (2005). Diffusivity of potassium sorbate in $\kappa$-carrageenan based antimicrobial film. $L W T$ - Food Science and Technology, 38, 417-423. doi: 10.1016/j.1wt.2004.07.004

[11] Denavi, G., Tapia-Blácido, D. R., Añón, M. C., Sobral, P. J. A., Mauri, A. N., \& Menegalli, F. C. (2009). Effects of drying conditions on some physical properties of soy protein films. Journal of Food Engineering, 90, 341-349. doi: 10.1016/j.jfoodeng.2008.07.001

[12] Detduangchan, N., Sridach, W., \& Wittaya, T. (2014). Enhancement of the properties of biodegradable rice starch films by using chemical crosslinking agents. International Food Research Journal(3), 1225-1235.

[13] Farhan, A., \& Hani, N. M. (2017). Characterization of edible packaging films based on semi-refined kappa-carrageenan plasticized with glycerol and sorbitol. Food Hydrocolloids, 64, 48-58. doi: 10.1016/j.foodhyd.2016.10.034

[14] Galus, S., \& Lenart, A. (2013). Development and characterization of composite edible films based on sodium alginate and pectin. Journal of Food Engineering, 115, 459-465. doi: 10.1016/j.jfoodeng.2012.03.006

[15] Garcia, M. A., Pinotti, A., \& Zaritzky, N. E. (2006). Physicochemical, water vapor barrier and mechanical properties of corn starch and chitosan composite films. Starch/Staerke, 58, 453-463. doi: 10.1002/star.200500484

[16] Ghafari, S., Aziz, H. A., Isa, M. H., \& Zinatizadeh, A. A. (2009). Application of response surface methodology (RSM) to optimize coagulation-flocculation treatment of leachate using poly-aluminum chloride (PAC) and alum. Journal of Hazardous Materials, 163, 650-656. doi: 10.1016/j.jhazmat.2008.07.090

[17] Ghosh, S., \& Swaminathan, T. (2003). Optimization of Process Variables for the Extractive Fermentation of 2 , 3-Butanediol by Klebsiella oxytoca in Aqueous Two-phase System Using Response Surface Methodology. Chem.Biochem.Eng, 17, 319-325.

[18] Halim, S. F. A., Kamaruddin, A. H., \& Fernando, W. J. N. (2009). Continuous biosynthesis of biodiesel from waste cooking palm oil in a packed bed reactor: Optimization using response surface methodology (RSM) and mass transfer studies. Bioresource Technology, 100, 710-716. doi: 10.1016/j.biortech.2008.07.031

[19] Kanatt, S. R., Rao, M. S., Chawla, S. P., \& Sharma, A. (2012). Active chitosan-polyvinyl alcohol films with natural extracts Food Hydrocolloids, 29, 290-297. doi 10.1016/j.foodhyd.2012.03.005

[20] Kerry, C., \& Huber, E. M. (2009). Edible Film and Coating For Food Aplication.

[21] Kurt, A., \& Kahyaoglu, T. (2014). Characterization of a new

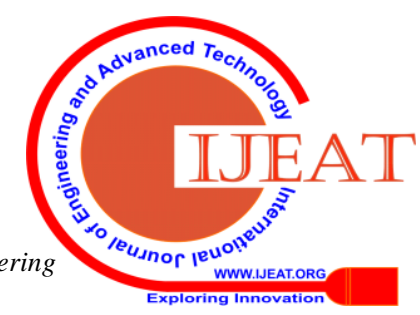


biodegradable edible film made from salep glucomannan. Carbohydrate Polymers, 104, 50-58. doi: 10.1016/j.carbpol.2014.01.003

[22] Larotonda, F. D. S., Torres, M. D., Gonçalves, M. P., Sereno, A. M., \& Hilliou, L. (2016). Hybrid carrageenan-based formulations for edible film preparation: Benchmarking with kappa carrageenan. Journal of Applied Polymer Science, 133, 1-10. doi: 10.1002/app.42263

[23] Limpan, N., Prodpran, T., Benjakul, S., \& Prasarpran, S. (2010). Properties of biodegradable blend films based on fish myofibrillar protein and polyvinyl alcohol as influenced by blend composition and $\mathrm{pH}$ level. Journal of Food Engineering, $\quad 100, \quad 85-92 . \quad$ doi: 10.1016/j.jfoodeng.2010.03.031

[24] Limpan, N., Prodpran, T., Benjakul, S., \& Prasarpran, S. (2012). Influences of degree of hydrolysis and molecular weight of poly(vinyl alcohol) (PVA) on properties of fish myofibrillar protein/PVA blend films. Food Hydrocolloids, 29, 226-233. doi: 10.1016/j.foodhyd.2012.03.007

[25] Liyana-Pathirana, C., \& Shahidi, F. (2005). Optimization of extraction of phenolic compounds from wheat using response surface methodology. Food Chemistry, 93, 47-56. doi: 10.1016/j.foodchem.2004.08.050

[26] Maran, J. P., Sivakumar, V., Sridhar, R., \& Thirugnanasambandham, K. (2013). Development of model for barrier and optical properties of tapioca starch based edible films. Carbohydrate Polymers, 92, 1335-1347. doi: 10.1016/j.carbpol.2012.09.069

[27] Maria, T. M. C., de Carvalho, R. A., Sobral, P. J. A., Habitante, A. M. B. Q., \& Solorza-Feria, J. (2008). The effect of the degree of hydrolysis of the PVA and the plasticizer concentration on the color, opacity, and thermal and mechanical properties of films based on PVA and gelatin blends. Journal of Food Engineering, 87, 191-199. doi: 10.1016/j.jfoodeng.2007.11.026

[28] Martins, J. T., Bourbon, A. I., Pinheiro, A. C., Souza, B. W. S., Cerqueira, M. A., \& Vicente, A. A. (2013). Biocomposite Films Based on $\kappa$-Carrageenan/Locust Bean Gum Blends and Clays: Physical and Antimicrobial Properties. Food and Bioprocess Technology, 6, 2081-2092. doi: 10.1007/s11947-012-0851-4

[29] McHugh, \& Krochta. (1994). Edible coatings and film to improve food quality. USA: Echnomic Publ.Co.

[30] Meng, F., Zhang, Y., Xiong, Z., Wang, G., Li, F., \& Zhang, L. (2018). Mechanical, hydrophobic and thermal properties of an organic-inorganic hybrid carrageenan-polyvinyl alcohol composite film. Composites Part B: Engineering, 143, 1-8. doi: 10.1016/j.compositesb.2017.12.009

[31] Monjazeb Marvdashti, L., Koocheki, A., \& Yavarmanesh, M. (2017). Alyssum homolocarpum seed gum-polyvinyl alcohol biodegradable composite film: Physicochemical, mechanical, thermal and barrier properties. Carbohydrate Polymers, 155, 280-293. doi: 10.1016/j.carbpol.2016.07.123

[32] Montgomery, D. (2001). Introduction to Statistical Quality Control (4 ed. Vol. 2). Chicago John Wiley \& Sons.

[33] Muppalla, S. R., Kanatt, S. R., Chawla, S. P., \& Sharma, A. (2014). Carboxymethyl cellulose-polyvinyl alcohol films with clove oil for active packaging of ground chicken meat. Food Packaging and Shelf Life, 2, 51-58. doi: 10.1016/j.fps1.2014.07.002

[34] Muthukumar, M., Mohan, D., \& Rajendran, M. (2003). Optimization of mix proportions of mineral aggregates using Box Behnken design of experiments. Cement and Concrete Composites, 25, 751-758. doi: 10.1016/S0958-9465(02)00116-6

[35] Noordin, M. Y., Venkatesh, V. C., Sharif, S., Elting, S., \& Abdullah, A. (2004). Application of response surface methodology in describing the performance of coated carbide tools when turning AISI 1045 steel. Journal of Materials
Processing Technology, 145, 46-58. doi: 10.1016/S0924-0136(03)00861-6

[36] Plastic Packaging: Interactions with Food and Pharmaceuticals (WILEY-VCH Verlag GmbH \& Co KGaA 2008). Second, Co.

[37] Ramakrishnan, R., \& Arumugam, R. (2012). Application of Response Surface Methodology (RSM) for Optimization of Operating Parameters and Performance Evaluation of Cooling Tower Cold Water Temperature. An International Journal of Optimization and Control: Theories \& Applications (IJOCTA), 2, 39-50. doi: 10.11121/ijocta.01.2012.0093

[38] Rhim, J. W., \& Wang, L. F. (2013). Mechanical and water barrier properties of agar/ $\kappa$-carrageenan/konjac glucomannan ternary blend biohydrogel films. Carbohydrate Polymers, 96, 71-81. doi: 10.1016/j.carbpol.2013.03.083

[39] Rouhi, M., Razavi, S. H., \& Mousavi, S. M. (2017). Optimization of crosslinked poly(vinyl alcohol) nanocomposite films for mechanical properties. Materials Science and Engineering $C, 71,1052-1063$. doi: 10.1016/j.msec.2016.11.135

[40] Shahbazi, M., Rajabzadeh, G., Rafe, A., \& Ettelaie, R. (2017). Food Hydrocolloids Physico-mechanical and structural characteristics of blend film of poly ( vinyl alcohol ) with biodegradable polymers as affected by disorder- to-order conformational transition. Food hydrocolloids. doi: 10.1016/j.foodhyd.2017.04.017

[41] Sharma, N., Khanna, R., Gupta, R. D., \& Sharma, R. (2013). Modeling and multiresponse optimization on WEDM for HSLA by RSM. International Journal of Advanced Manufacturing Technology, 67, 2269-2281. doi: 10.1007/s00170-012-4648-4

[42] Shojaee-Aliabadi, S., Hosseini, H., Mohammadifar, M. A., Mohammadi, A., Ghasemlou, M., Hosseini, S. M., \& Khaksar, R. (2014). Characterization of $\kappa$-carrageenan films incorporated plant essential oils with improved antimicrobial activity. Carbohydrate Polymers, 101, 582-591. doi: 10.1016/j.carbpol.2013.09.070

[43] Silva. (2008). Biodegradable films based on blends of gelatin and poly(vinyl alcohol): effect of PVA type or concentration on some physical properties of films. Journal of Polymers and the Environment, 276-285.

[44] Handbook of Biopolymers and Biodegradable Plastics : Properties, Processing and Applications (William Adrew 2013).

[45] Singh, T. P., Chatli, M. K., \& Sahoo, J. (2015). Development of chitosan based edible films: process optimization using response surface methodology. Journal of Food Science and Technology, 52, 2530-2543. doi: 10.1007/s13197-014-1318-6

[46] Srinivasa, P. C., Ramesh, M. N., Kumar, K. R., \& Tharanathan, R. N. (2003). Properties and sorption studies of chitosan-polyvinyl alcohol blend films. Carbohydrate Polymers, 53, 431-438. doi: 10.1016/S0144-8617(03)00105-X

[47] Tang, X., \& Alavi, S. (2011). Recent advances in starch, polyvinyl alcohol based polymer blends, nanocomposites and their biodegradability. Carbohydrate Polymers, 85, 7-16. doi: 10.1016/j.carbpol.2011.01.030

[48] Tavassoli-Kafrani, E., Shekarchizadeh, H., \& Masoudpour-Behabadi, M. (2016). Development of edible films and coatings from alginates and carrageenans. Carbohydrate Polymers, 137, 360-374. doi: 10.1016/j.carbpol.2015.10.074

[49] Thakur, R., Pristijono, P., Golding, J. B., Stathopoulos, C. E. Scarlett, C. J., Bowyer, M., . . . Vuong, Q. V. (2017). Amylose-lipid complex as a measure of variations in physical, mechanical and barrier attributes of rice starch- 1 -carrageenan biodegradable edible film. Food Packaging and Shelf Life, 14, 108-115. 
doi: 10.1016/j.fpsl.2017.10.002

[50] Tripathi, S., Mehrotra, G. K., \& Dutta, P. K. (2010).

Preparation and physicochemical evaluation of chitosan/poly(vinyl alcohol)/pectin ternary film for food-packaging applications. Carbohydrate Polymers, 79, 711-716. doi: 10.1016/j.carbpol.2009.09.029

[51] Vieira, M. G. A., Da Silva, M. A., Dos Santos, L. O., \& Beppu, M. M. (2011). Natural-based plasticizers and biopolymer films: A review. European Polymer Journal, 47, 254-263. doi: 10.1016/j.eurpolymj.2010.12.011

[52] Woranuch, S., Yoksana, R., \& Akashi, M. (2015). Ferulic acid-coupled chitosan: Thermal stability and utilization as an antioxidant for biodegradable active packaging film. Carbohydrate Polymers, 115, 744-751. doi: 10.1016/j.carbpol.2014.06.074

[53] Zhong, Y., \& Li, Y. (2011). Effects of surfactants on the functional and structural properties of kudzu (Pueraria lobata) starch/ascorbic acid films. Carbohydrate Polymers, 85, 622-628. doi: 10.1016/j.carbpol.2011.03.031 